\title{
SEMI-DESTRUCTIVE APPROACH IN DEVELOPING ALLOMETRIC BIOMASS FOR CHUKRASIA TABULARIS IN SYLHET REGION OF BANGLADESH
}

\author{
Tipu MTK ${ }^{1}$, Manzoor Rashid AZM ${ }^{1, *}$, Tahasina $\mathbf{C}^{1} \& \operatorname{Mahmood~} \mathbf{H}^{2}$ \\ ${ }^{1}$ Department of Forestry and Environmental Science, Shahjalal University of Science and Technology, Sylhet-3114, \\ Bangladesh \\ ${ }^{2}$ Forestry and Wood Technology Discipline, Khulna University, Khulna-9208 Bangladesh
}

*pollen_forest@yahoo.com

Submitted May 2020; accepted September 2020

\begin{abstract}
Species-specific biomass allometric model was crucial to measure tree biomass especially on major tree species in forests in view of their ecological and economic values. The dependent on common biomass models during forest inventory may produce inaccurate estimates since tree structure and growth varied from species and regions. In this aspect, the study aimed to derive the best-fit allometric model to estimate aboveground biomass of Chukrasia tabularis in Sylhet Region of Bangladesh. A semi destructive method where total height $(\mathrm{H})$, diameter at breast height $(\mathrm{D})$ and wood density were used as independent variables to check the efficiency of the commonly used pan-tropical models in biomass estimation of the species. A total of 120 individual trees were purposively selected for model development and validation. Ten regression equations were tested in the study for biomass allometric model and seven for predicting height-diameter at breast height relationship. The best-fit model was selected based on adjusted $\mathrm{R}^{2}$, residual standard error, the Akaike information criterion and Akaike weights. Finally, the derived model was compared with the commonly used pan-tropical biomass models in terms of model efficiency and root mean square error. The

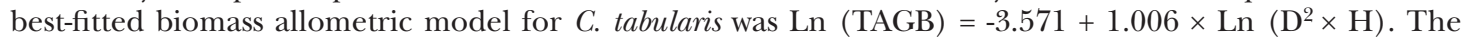
derived best-fit model showed higher efficiency in biomass estimation compared to the commonly used pan-tropical models.
\end{abstract}

Keywords: Allometry, above-ground biomass, biomass estimation method, species-specific model, tropical forest.

\section{INTRODUCTION}

Deforestation and forest degradation caused by different landuse systems accounted for about $25 \%$ of global carbon emissions over the period 1870-2014 (Le Quéré et al. 2014) . In recent years, various initiatives such as REDD ${ }^{+}$were practiced to reduce global carbon emission and enhance carbon sequestration in forests (Alexander 2018). Nevertheless, proper implementation of those initiatives required authentic ground-based monitoring of global carbon storage (Fearnside 2012, Tulyasuwan et al. 2012). Presently, carbon monitoring is widely used based on remotesensing and GIS techniques and observed in many recent studies (Aricak et al. 2015, Bindu et al. 2018). Nevertheless, their calibrations required accurate ground-based biomass and carbon storage estimation (Asner et al. 2010, Saatchi et al. 2011, Clark \& Kellner 2012). Biomass estimation was directly related to the studies of carbon sequestration and assisted in conducting forest inventory and strengthens sustainable management (Picard et al. 2012).

Allometric model was commonly used to measure tree biomass by taking the tree biometric measurements (Brown 1997). However, there were uncertainties regarding the quality of these allometric models in assessing aboveground biomass (Chave et al. 2014, Clark \& Kellner 2012, Sileshi 2014). Appropriate model selection has significant effect on the accuracy of biomass stock measurement. Moreover, tree species posed considerable impacts on both ecology and economy. A good species-specific biomass allometric model, would enable proper management of the selected area(Mahmood et al. 2019a). Biomass allometric models basically referred to mathematical functions by which the relationship between tree biomass with 
tree diameter at breast height or wood density were represented for a distinct species or a community (Ketterings et al. 2001, Sileshi 2014). The inclusion of more variables such as tree height in biomass allometric models generally yielded less biased estimates (Chave et al. 2005). In the tropics, pan-tropical biomass allometric models were suggested by Chave et al. (2005) and commonly used for biomass estimation of trees (Nam et al. 2016). In many instances, these models produced less accurate estimates compared to the species-specific and site-specific models due to the spatial variability (Van Breugel et al. 2011). Therefore, species-specific and site-specific biomass allometric models were preferred over the use of common models (Mahmood et al. 2015).

Destructive method for developing allometric model is the most accurate for biomass estimation, but it requires time and intensive labour to increase the sample areas and sample sizes. (Ketterings et al. 2001, Deb et al. 2012). The development of allometric models using nondestructive technique is sometimes limited to stem biomass. In this aspect, the semi-destructive approach offers a solution in the development of allometric biomass model and can easily be conducted in reserved areas (Picard et al. 2012, Mahmood et al. 2020).

Chukrasia tabularis is a tropical hill forest tree species. It is distributed from India to Indonesia (Kalinganire \& Pinyopusarek 2000). In Bangladesh, this species is mostly found in Sylhet region. Presently, C. tabularis needed special attention for its various applications including high-valued commercial use. There are 222 validated allometric volume and biomass allometric models in Bangladesh but only a small area of forest trees species are included (Mahmood et al. 2019b). In a recent study by Mahmood et al. (2019b), 14 hill forest tree species were considered in order to derive a common allometric model for the estimation of tree above ground biomass in the hill region of Bangladesh. However, C. tabularis being one of the most significant hill forest tree species was not included and had not been studied. With this regard, the study aimed to derive the relationship between total height and diameter at breast height of $C$. tabularis, to develop a related speciesspecific allometric biomass model and to check the efficiency of the commonly used pan-tropical models in biomass estimation of this species.

\section{MATERIALS AND METHODS}

\section{Study area}

The study was conducted in Rema-Kalenga Wildlife Sanctuary $\left(24^{\circ} 06^{\prime}-24^{\circ} 14^{\prime} \mathrm{N}\right.$ and $91^{\circ}$ $35^{\prime}-91^{\circ} 40^{\prime} \mathrm{E}$ ) (Figure 1). It is the largest upland wildlife sanctuary in Bangladesh, which falls under Habiganj Forest Range-2 in Sylhet Forest Division. The study area has tropical moist climate and a characteristics high rainfall from May to August (Holdridge 1967, Islam et al. 2018). The annual average rainfall and temperature are $2363 \mathrm{~mm}$ and $24.8^{\circ} \mathrm{C}$ respectively over the period 1950-2015 (Islam et al. 2018). The soil texture of the study area varies from clay loams on level ground to sandy loams on hilly ground (Hassan 1994). The study site has dominating plant species such as Chukrasia tabularis, Dipterocarpus turbinatus, Tectona grandis, Toona ciliata, Syzygium grandis, Lagerstroemia speciose and different species of Albizia (Islam et al. 2018).

\section{Sampling and measurement of sample trees}

A total of 120 C. tabularis individual trees were selected purposively from the study area. Trees with broken top, damaged, hollow trunk and evidence of suppression or disease were discarded during the selection. In the first event, 98 individuals were chosen to derive the allometric model, covering diameter at breast height and total height range of 9-52 cm and 9-37 m respectively. Seven diameter classes were taken to cover the diameter at breast height range starting from $9.0-15.1 \mathrm{~cm}$, $15.1-21.2 \mathrm{~cm}, 21.2-27.3 \mathrm{~cm}, 27.3-33.4 \mathrm{~cm}$, $33.4-39.5 \mathrm{~cm}, 39.5-45.6 \mathrm{~cm}$ and $45.6-51.7 \mathrm{~cm}$. Fourteen individuals were selected from each classes. In the second event, 22 individuals were selected from those classes for model validation and evaluation. Diameter at breast height and total height of the trees were measured and recorded. Sectional volume of tree stem and the bigger branches (diameter $>7 \mathrm{~cm}$ ) of the sampled trees were measured using semidestructive method as described in Mahmood et al. (2016). The base diameters of all small branches (diameter $\leq 7 \mathrm{~cm}$ ) of each sample tree were measured by climbing on to the tree. A total of 30 smaller branches were trimmed from different trees at base and their base diameters were recorded separately. 


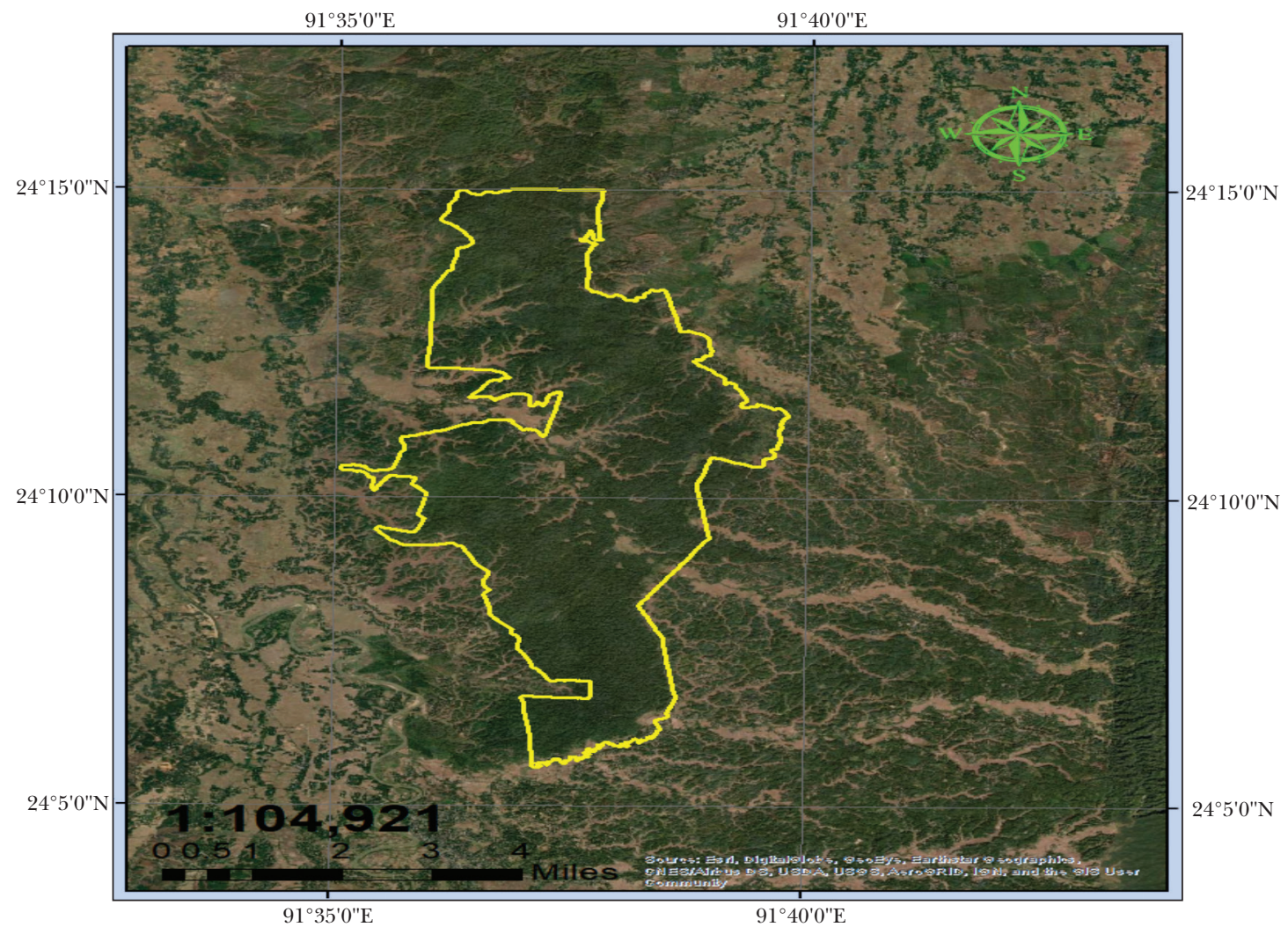

Figure 1 Location of the study site

\section{Wood density measurement}

As logging is banned in reserved forest, an individual C. tabularis was felled from the outside the forest for wood density estimation. One representative stem disc about $7.5 \mathrm{~cm}$ thick was taken from the base, middle and top portion of the sampled tree. Six sub-samples of wood $(2.5 \mathrm{~cm} \times 2.5 \mathrm{~cm} \times 7.5 \mathrm{~cm})$ were collected from each disk at $2 \mathrm{~cm}$ interval from periphery to the centre of disk. The wood samples was oven dried at $105{ }^{\circ} \mathrm{C}$ until constant weight was achieved and the weight of the oven-dried samples were measured by using high-precision digital laboratory balance. Volume of the samples was measured using water displacement method (Picard et al. 2012, Mahmood et al. 2016). Finally, the wood density of C. tabularis was derived using equation (1).

$$
\begin{aligned}
& \text { Wood density } \\
& \left(\mathrm{kg} \mathrm{m}^{-3}\right)
\end{aligned}=\frac{\text { Oven-dry weight of sample }(\mathrm{kg})}{\text { Fresh volume of the sample }\left(\mathrm{m}^{3}\right)}
$$

\section{Height-diameter at breast height relationship} of C. tabularis

A total of seven models $(\mathrm{H}=\mathrm{a}+\mathrm{b}(\mathrm{D}), \mathrm{H}=\mathrm{a}+$ b $(1 / D), 1 / \mathrm{H}=\mathrm{a}+\mathrm{b}(1 / \mathrm{D}), \mathrm{H}=\mathrm{a}+\mathrm{b} \operatorname{Ln}(\mathrm{D})$, $\operatorname{Ln}(\mathrm{H})=\mathrm{a}+\mathrm{b}(1 / \mathrm{D}), \operatorname{Ln}(1 / \mathrm{H})=\mathrm{a}+\mathrm{b}(\mathrm{D})$ and $\operatorname{Ln}(\mathrm{H})=\mathrm{a}+\mathrm{b} \operatorname{Ln}(\mathrm{D}))$ were used to derive the height-diameter at breast height relationships (Parresol 1992, Vanclay 1995, Mahmood et al. 2019c). The model which showed the lowest residual standard error (RSE) and the highest coefficient of determination (adjusted $R^{2}$ ) was selected as the best fit model (Picard et al. 2012).

\section{Development of branch allometry}

The trimmed small branches were separated into leaves, leaves containing smaller branches and woody part. The fresh weight of each part was measured in the field using a portable digital balance. Thirty sub-samples (about $250 \mathrm{~g}$ each) from each part were collected and put into air tight zip-polybag to avoid rapid moisture loss. The collected samples were taken immediately 
to the laboratory, where conversion ratio of fresh to oven-dry weight was derived at $70{ }^{\circ} \mathrm{C}$. The conversion ratio of respective parts were multiplied with the fresh weight of branch parts to get oven-dry weight of branch parts (Mahmood et al. 2019c).

Base diameter of smaller branches and biomass of branch components (leaf, leaf containing smaller branch and woody parts of branch) were considered as predictor and output variables respectively. These variables were transformed into natural logarithm (Ln) to derive the branch allometric biomass models. Models having highest adjusted $\mathrm{R}^{2}$ value and lowest residual standard error (RSE) as well as AIC value were selected as best fit model (Mahmood et al. 2019c). For bias minimisation of Ln transformed equations, a correction factor (CF) was calculated (Sprugel 1983). The developed branch allometry model was used to enumerate the biomass of the smaller branches (diameter $\leq 7 \mathrm{~cm}$ ) of the trees.

\section{Biomass of stem and bigger branches}

Sectional volume of stem and bigger branches were measured using the Newton's formula as in equation 2 (Cruz de León \& Uranga-Valencia 2013).

$$
\mathrm{V}=\frac{\mathrm{S}_{1}+4 \mathrm{~S}_{\mathrm{m}}+\mathrm{S}_{2}}{6} \times \mathrm{L}
$$

where, $\mathrm{V}$ is the volume of the section, $\mathrm{S}_{1}$ is the cross-sectional area at the large end, $\mathrm{S}_{\mathrm{m}}$ is the cross-sectional area at the middle, $\mathrm{S}_{2}$ is the crosssectional area at the small end and $\mathrm{L}$ is length of the section.

Finally, stem and bigger branch biomass were enumerated using equation 3 (Mahmood et al. 2016).

Biomass $=$ Volume $\left(\mathrm{m}^{3}\right) \times$ Wood density $\left(\mathrm{kg} \mathrm{m}^{-3}\right)$

\section{Allometric biomass models for total above ground biomass}

Total above ground biomass (TAGB) was calculated by adding the biomass of stem, bigger branches and smaller branches. Total height and diameter at breast height were considered as predictor variables and biomass as response variable. Ten frequently used equations, as shown in Table 1, were tested to derive the best-fit allometric biomass (Brown et al. 1997, Nelson et al. 1999, Deb et al. 2012, Mahmood et al. 2019b).

The model having the lowest Akaike Information Criterion (AIC) and Residual Standard Error (RSE), and the highest Akaike Information Criterion weight (AICw) and adjusted $\mathrm{R}^{2}$ values was selected as best fit model. However, models having RSE value greater than 0.30 were discarded and not allowed for further validation and comparison (Picard et al. 2012, Sileshi 2014, Mahmood et al. 2019a) . In addition, Durbin-Watson (D-value) test was conducted to check autocorrelation in the error

Table 1 Functions tested for developing allometric model

\begin{tabular}{cll}
\hline Model no & Equation & Type \\
\hline 1 & TAGB $=\mathrm{a}+\mathrm{b} \times(\mathrm{D})$ & Linear \\
2 & TAGB $=\mathrm{a}+\mathrm{b} \times(\mathrm{D})+\mathrm{c} \times(\mathrm{D} \times \mathrm{H})$ & Linear \\
3 & TAGB $=\mathrm{a}+\mathrm{b} \times\left(\mathrm{D}^{2} \times \mathrm{H}\right)$ & Linear \\
4 & Ln $(\mathrm{TAGB})=\mathrm{a}+\mathrm{b} \times \operatorname{Ln}(\mathrm{D})$ & Log-linear \\
5 & Ln $(\mathrm{TAGB})=\mathrm{a}+\mathrm{b} \times \operatorname{Ln}(\mathrm{H})$ & Log-linear \\
6 & Ln $($ TAGB $)=\mathrm{a}+\mathrm{b} \times \operatorname{Ln}(\mathrm{D} \times \mathrm{H})$ & Log-linear \\
7 & Ln $($ TAGB $)=\mathrm{a}+\mathrm{b} \times \operatorname{Ln}\left(\mathrm{D}^{2} \times \mathrm{H}\right)$ & Log-linear \\
8 & Ln $($ TAGB $)=\mathrm{a}+\mathrm{b} \times \operatorname{Ln}(\mathrm{D})+\mathrm{Ln}(\mathrm{H})$ & Log-linear \\
9 & $\operatorname{Ln}(\mathrm{TAGB})=\mathrm{a}+\mathrm{b} \times \operatorname{Ln}\left(\mathrm{D}^{2}\right)$ & Log-linear \\
\hline
\end{tabular}

$\mathrm{Ln}=$ natural Log, TAGB = total above ground biomass, $\mathrm{D}=$ diameter at breast height, $\mathrm{H}=$ total height of the tree 
terms (Robinson \& Hamann 2010, Picard et al. 2012). Multicollinearity among the predictors in a model was checked using variance influential factor (VIF), where the test results of VIF $>5$ indicated the existence of multicollinearity (Sileshi 2014). Shapiro-Wilk (SW) test was conducted to check the normality of residuals of the models. Finally, a correction factor (CF) was calculated for bias minimization of $\mathrm{Ln}$ transformed equation (Sprugel 1983).

\section{Model validation}

The selected best-fit total above ground biomass (TAGB) model was validated and compared with the commonly used pan-tropical biomass models of Brown (1997) and Chave et al. (2005) using the data set of the second event in terms of model efficiency (ME) and root mean square error percentage. Model efficiency was calculated using equation 4. Model efficiency value close to 1 was regarded as near perfect (Mayer \& Butler 1993).

$$
\text { Model efficiency }=1-\left[\frac{\Sigma\left(Y_{o}-Y_{p}\right)^{2}}{\Sigma\left(Y_{o}-\bar{Y}\right)^{2}}\right]
$$

where, $\mathrm{Y}_{\mathrm{p}}$ is the predicted biomass from model; $\mathrm{Y}_{\mathrm{o}}$ is the observed biomass in field measurement and $\bar{Y}$ is the mean of the observed biomass.

Observed biomass and predicted biomass were regressed, where $\mathrm{Y}_{\mathrm{p}}$ was kept in the $\mathrm{X}$-axis and $Y_{o}$ in the Y-axis. It helped to compare the best-fit model with the pan-tropical models. Significance of slope $(b=1)$ and intercept $(a=0)$ were also tested to understand the overestimation or underestimation of the predicted biomass of each model from 1:1 line (Piñeiro et al. 2008, Sileshi 2014). Every statistical analysis was conducted using $R$ (3.5.2) software. The alpha level for all statistical analysis was 0.05 .

\section{RESULTS}

\section{Wood density and height-diameter at breast height relationship}

Wood density of C. tabularis was found varying between 0.44 and $0.64 \mathrm{~g} \mathrm{~cm}^{-3}$ while the average was $0.55 \mathrm{~g} \mathrm{~cm}^{-3}$ with a standard deviation of 0.06 . The linear model $(1 / \mathrm{H}=0.024+0.643 \times(1 / \mathrm{D}))$ appeared as best-fit model for total height and diameter at breast height relationship with the highest adjusted $\mathrm{R}^{2}$ value (0.617) and lowest RSE value (0.011) showed in Table 2.

\section{Allometric models for the smaller branches}

The best-fit models for leaf, leaf containing smaller branches (LCSB), woody parts of smaller branches (WSB) and total biomass of smaller branches were leaf $=-0.25+0.196 \times$ base diameter, $\mathrm{LCSB}=-0.245+0.139 \times$ base diameter, $\mathrm{Ln}(\mathrm{WSB})=-2.945+2.097 \times \mathrm{Ln}$ (base diameter and $\operatorname{Ln}$ (branch biomass) $=-2.111+1.926 \times \operatorname{Ln}$ (base diameter)) respectively (Table 3 ).

\section{Allometric models for total aboveground biomass}

The linear models tested in the study showed higher RSE and AIC value. Model 7 (Ln (TAGB) $\left.=-3.571+1.006 \times \operatorname{Ln}\left(D^{2} \times H\right)\right)$ showed the lowest AIC value (4.893) and RSE value (0.243) and

Table 2 Estimated parameters of different models to derive height $(\mathrm{H})$ and diameter at breast height (D) relationship

\begin{tabular}{clrrrr}
\hline $\begin{array}{c}\text { Model } \\
\text { no. }\end{array}$ & Equation & $\mathrm{a}$ & $\mathrm{b}$ & Adj. $\mathrm{R}^{2}$ & RSE \\
\hline 1 & $\mathrm{H}=\mathrm{a}+\mathrm{b}(\mathrm{D})$ & 13.257 & 0.273 & 0.260 & 5.566 \\
2 & $\mathrm{H}=\mathrm{a}+\mathrm{b}(1 / \mathrm{D})$ & 29.341 & -189.418 & 0.424 & 4.909 \\
3 & $1 / \mathrm{H}=\mathrm{a}+\mathrm{b}(1 / \mathrm{D})$ & 0.024 & 0.643 & 0.617 & 0.011 \\
4 & $\mathrm{H}=\mathrm{a}+\mathrm{b}$ Ln (D) & -5.708 & 8.238 & 0.359 & 5.178 \\
5 & $\mathrm{Ln}(\mathrm{H})=\mathrm{a}+\mathrm{b}(1 / \mathrm{D})$ & 3.462 & -10.659 & 0.544 & 0.217 \\
6 & Ln $(1 / \mathrm{H})=\mathrm{a}+\mathrm{b}(\mathrm{D})$ & -2.553 & -0.015 & 0.340 & 0.262 \\
7 & Ln $(\mathrm{H})=\mathrm{a}+\mathrm{b}$ Ln $(\mathrm{D})$ & 1.491 & 0.463 & 0.460 & 0.236 \\
\hline
\end{tabular}

$\mathrm{Ln}=$ natural Log, RSE $=$ residual standard error 
Table 3 Allometric model for smaller branches

\begin{tabular}{|c|c|c|c|c|c|c|}
\hline Equation & $\mathrm{a}$ & $\mathrm{b}$ & Adj. $R^{2}$ & RSE & AIC & $\mathrm{CF}$ \\
\hline Leaf $=\mathrm{a}+\mathrm{b} \times($ base diameter $)$ & -0.250 & 0.196 & 0.626 & 0.206 & -5.691 & \\
\hline $\operatorname{Ln}($ Leaf $)=a+b \times \operatorname{Ln}($ base diameter $)$ & -3.075 & 1.680 & 0.658 & 0.375 & 30.320 & 1.073 \\
\hline $\mathrm{LCSB}=\mathrm{a}+\mathrm{b} \times($ base diameter $)$ & -0.245 & 0.139 & 0.541 & 0.172 & -16.280 & \\
\hline $\operatorname{Ln}(\mathrm{LCSB})=\mathrm{a}+\mathrm{b} \times \operatorname{Ln}($ base diameter $)$ & -4.107 & 1.974 & 0.575 & 0.524 & 50.344 & 1.147 \\
\hline $\mathrm{WSB}=\mathrm{a}+\mathrm{b} \times($ base diameter $)$ & -1.271 & 0.592 & 0.779 & 0.429 & 38.346 & \\
\hline $\operatorname{Ln}(\mathrm{WSB})=\mathrm{a}+\mathrm{b} \times \mathrm{Ln}$ (base diameter) & -2.945 & 2.097 & 0.871 & 0.251 & 6.339 & 1.032 \\
\hline Branch biomass $=\mathrm{a}+\mathrm{b} \times($ base diameter $)$ & -1.768 & 0.928 & 0.797 & 0.638 & 62.144 & \\
\hline $\begin{array}{l}\text { Ln }(\text { Branch biomass })=\mathrm{a}+\mathrm{b} \times \mathrm{Ln} \text { (base } \\
\text { diameter) }\end{array}$ & -2.111 & 1.926 & 0.871 & 0.231 & 1.326 & 1.027 \\
\hline
\end{tabular}

Ln = natural Log, LCSB = leaf containing smaller branches, WSB = woody parts of smaller branches, $\mathrm{RSE}=$ residual standard error, $\mathrm{AIC}=$ Akaike Information Criterion, $\mathrm{CF}=$ correction factor

highest adjusted $\mathrm{R}^{2}$ value $(0.960)$ and $\mathrm{AICw}$ value (0.540) (Table 4).

Model 8 appeared as the closest candidate to model 7 but it was found to have higher AIC value (6.601) and lower AICw value (0.230). Finally, the back transformed model was:

$$
\begin{aligned}
& \operatorname{Ln}(\text { TAGB })=-3.571+1.006 \times \operatorname{Ln}\left(D^{2} \times H\right) \text { or } \\
& \text { TAGB }=\exp \left(-3.571+1.006 \times \operatorname{Ln}\left(D^{2} \times H\right)\right) \text { or } \\
& \text { TAGB }=0.028953 \times\left(D^{2} \times H\right)^{1.006}
\end{aligned}
$$

Hence, the bias corrected model was

$$
\begin{aligned}
& =1.029 \times 0.028953 \times\left(\mathrm{D}^{2} \times \mathrm{H}\right)^{\mathbf{1 . 0 0 6}} \\
& =0.029821 \times\left(\mathrm{D}^{2} \times \mathrm{H}\right)^{\mathbf{1 . 0 0 6}}
\end{aligned}
$$

\section{Model validation}

The best-fit model 7 showed the highest model efficiency value (0.972) and the lowest root mean square error value (13.119) compared to the commonly used regional and pan-tropical above ground biomass allometric models.

After comparing the observed against the predicted biomass, deviation was observed in biomass estimation from the line of significance of slope $(\mathrm{b}=1)$ and intercept $(\mathrm{a}=0)$ shown in Figure 2. It indicated that biomass allometric model of Chave et al. (2005) and Brown (1997) overestimated the biomass of the sample tree.

\section{DISCUSSION}

The appropriate selection of allometric models provided accuracy in biomass estimation of species (Nam et al. 2016). Careful investigation of model parameters was necessary in model selection (Sileshi 2014). Moreover, accurate measurements of independent variables such as tree height and diameter at breast height increased model acceptability and applicability (Overman et al. 1994). Addition of more variables such as wood density in biomass estimation model improved the validity of the model (Brown et al. 1989) and could be used as predictor variable in multi-species biomass model (Ebuy et al. 2011, Mahmood et al. 2019b) Wood density played a greater role as independent variable in biomass model for mixed species (Basuki et al. 2009). Many studies did not include wood density as predictor in species-specific allometric biomass model (Abich et al. 2019). Nevertheless, the study derived the mean wood density of C. tabularis which was quite similar with the local database of Sattar (1999).

The study covered a wide range of diameter at breast height $(9-52 \mathrm{~cm})$ and total height $(9-37 \mathrm{~m})$ of tree, which added confidence to the model validity. The $\log$ transformed model performed better for small branch biomass, which was in line with Mahmood et al. (2019b,c). Model 7 was selected as the best-fit model. In addition, the bias corrected model $($ TAGB $=0.029821 \times$ $\left.\left(D^{2} \times H\right)^{1.006}\right)$ was given for easier estimation of biomass. However, both models 6 and 8 showed statistical credibility as per the selection criteria (Sileshi 2014).

The best-fitted total aboveground biomass model developed in this study had the trend to over-estimate the biomass with increased diameter at breast height, which was evident in Figure 2. However, it showed higher model efficiency (0.972) compared to the commonly 

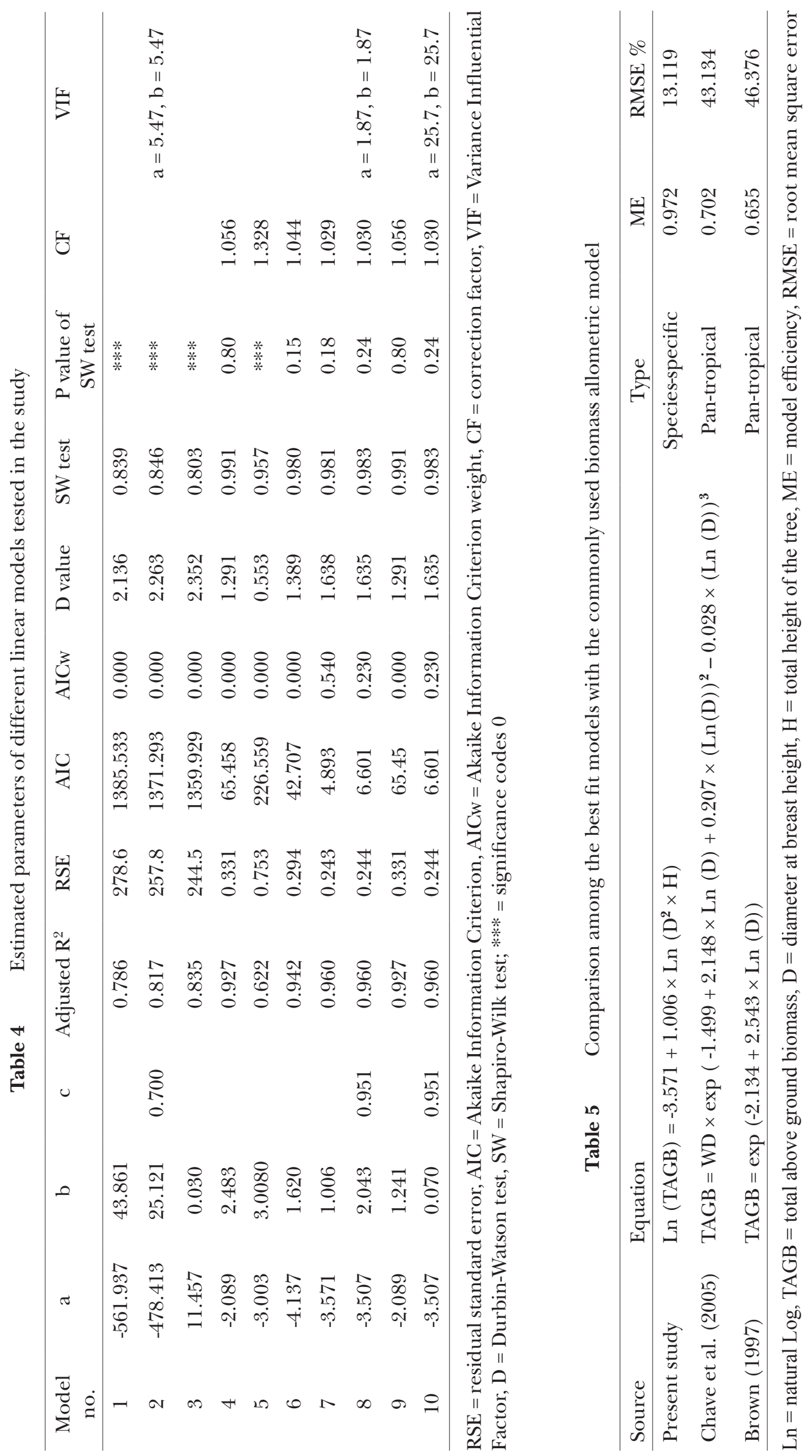

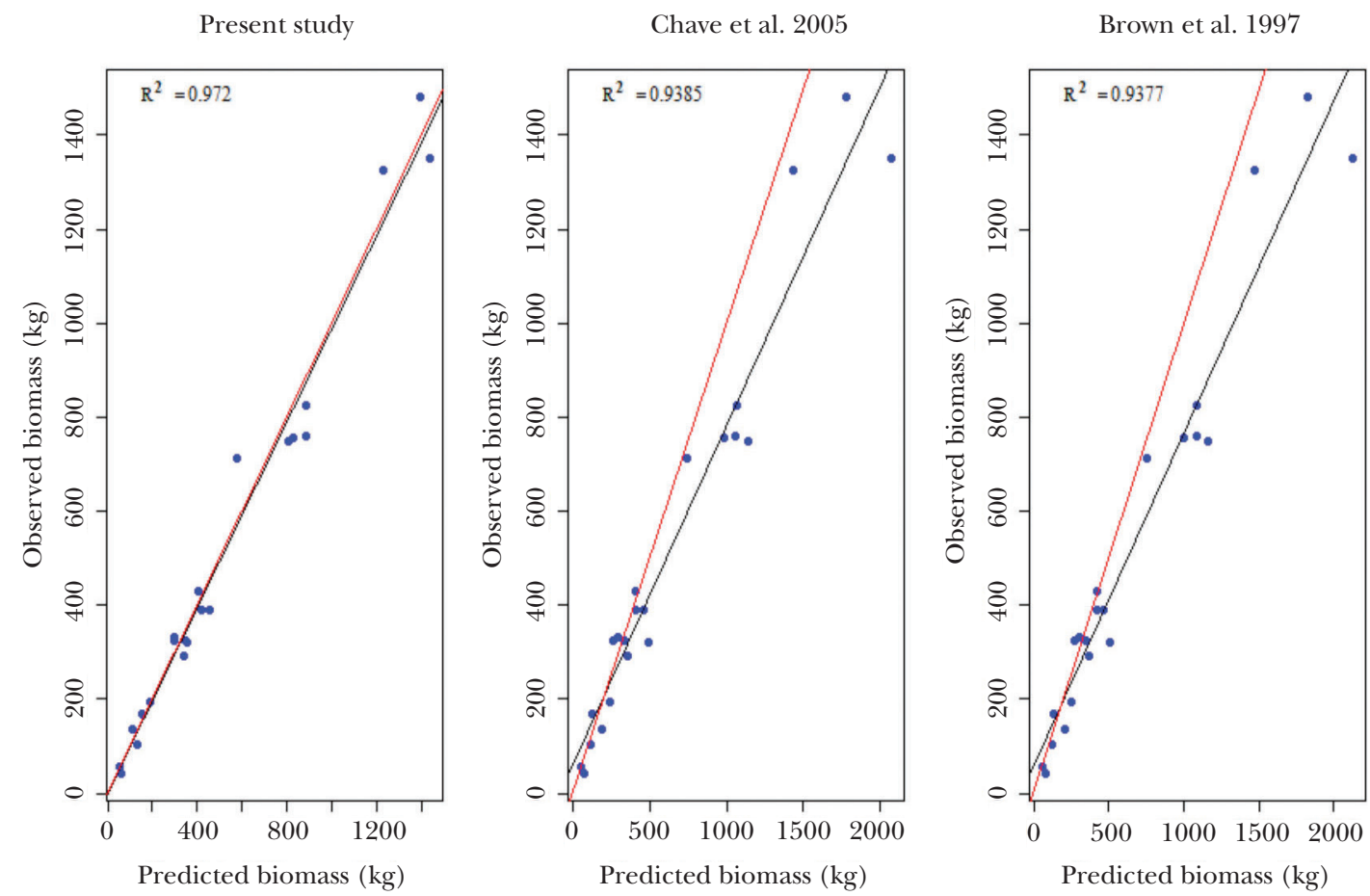

The black line is the regression line, and the red line is the significance of slope $(b=1)$ and intercept $(a=0)$

Figure 2 Regression analysis between observed and predicted values

used biomass allometric model of Brown (1997) and Chave et al. (2005) (Table 5). It showed the less efficiency of the common pan-tropical models in predicting biomass of this particular species. Significant deviations were found in those models due to inclusion of only diameter at breast height in biomass model (Nam et al. 2016). It was also found that in several previous studies, the use of common pan-tropical biomass estimation model generated more uncertainty than locally developed models (Maulana et al. 2016, Mahmood et al. 2020). The uncertainty was generally caused geographical positions, environmental factors, site condition and tree structure (Van Breugel et al. 2011, Nam et al. 2016).

The semi or non-destructive method was not very accurate and precise compared to the destructive method. There were sources of uncertainty related to biomass calculation using tree volume model, form factor, wood density and biomass expansion factor. About 10 to $16 \%$ of overestimation in biomass was expected at the stand level compared to the destructive method as stated by Njana (2017). In addition, significant error in the calculation might arise for larger trees with hollow trunk. Besides, using allometric equations in biomass estimation may result in small to very large percentage of error (Araújo et al. 1999). However, the study avoided such abnormalities of trees when higher model efficiency was found in the derived model compared to other pan-tropical models. Hence, the study had confidence of semi-destructive method in species-specific biomass estimation of tropical tree species (Mahmood et al. 2019c). Further studies are required to explore other factor of uncertainties in this method for mixed or specific species in the tropics.

The derived model for C. tabularis in the study was suggested to be applied for forest inventory in the tropics. It may also assist in the ground calibration of aboveground biomass estimation using remote sensing technique. However, the study was carried out based on a regional context and limited to the given range of diameter at breast height and total height of trees. Nevertheless, comprehensive and representative data were required to find a suitable model at national or global scale. In future studies, the procedure can be replicated to derive species-species local allometric biomass model for other tree species. 


\section{CONCLUSION}

The semi-destructive method in developing allometric model for biomass estimation is gaining growing popularity due to its high degree of precision and easy applicability in forests. The study estimated the mean wood density of C. tabularis separately to provide a site-specific value and the height-diameter at breast height relationship to generate further understanding about the species. The derived corrected bestfit model $\left(\right.$ TAGB $\left.=0.029821 \times\left(\mathrm{D}^{2} \times \mathrm{H}\right)^{1.006}\right)$ on C. tabularis in the study performed better than the commonly used pan-tropical biomass models in tropics. The findings of the study will contribute significantly to the future management and sustainable logging operation of C. tabularis in designated forest.

\section{ACKNOWLEDGEMENTS}

We acknowledge the Department of Forestry and Environmental Science of Shahjalal University of Science and Technology for the indispensable support in accomplishing the research.

\section{REFERENGES}

Abich A, Mucheye T, Tebkew M et AL. 2019. Species-specific allometric equations for improving aboveground biomass estimates of dry deciduous woodland ecosystems. Journal of Forestry Research. doi: 10.1007/ s11676-018-0707-5

AleXANDER S. 2018. Reducing emissions from deforestation and forest degradation. Pp 615-619 in The Wetland Book: I: Structure and Function, Management, and Methods. Springer, Dordrecht.

Araújo TM, Higuchi N \& Júnior JA. 1999. Comparison of formulae for biomass content determination in a tropical rain forest site in the state of Pará, Brazil. Forest Ecology and Management 117: 43-52.

Aricak B, Bulut A, Altunel A et al. 2015. Estimating above-ground carbon biomass using satellite image reflection values: a case study in camyazi forest directorate, Turkey. Sumarski List 139: 369-376.

Asner GP, Powell GVN, Mascaro J et al. 2010. Highresolution forest carbon stocks and emissions in the Amazon. Proceedings of the National Academy of Sciences of the United States of America 107: 16738-16742.

Basuki TM, Van LaAke PE, Skidmore AK et al. 2009. Allometric equations for estimating the above-ground biomass in tropical lowland dipterocarp forests. Forest Ecology and Management 257: 1684-1694.

Bindu G, Rajan P, Jishnu ES et al. 2018. Carbon stock assessment of mangroves using remote sensing and geographic information system. Egyptian Journal of Remote Sensing and Space Science. doi:10.1016/j. ejrs.2018.04.006
Brown S, Gillespie AJR \& Lugo AE. 1989. Biomass estimation methods for tropical forests with applications to forest inventory data. Forest Science 35: 881-902.

Brown S. 1997. Estimating Biomass and Biomass Change of Tropical Forests: A Primer. FAO Forestry Paper 134. Rome.

Chave J, Andalo C, Brown S et al. 2005. Tree allometry and improved estimation of carbon stocks and balance in tropical forests. Oecologia 145: 87-99.

Chave J, RéJou-Méchain M, Búrquez A et Al. 2014. Improved allometric models to estimate the aboveground biomass of tropical trees. Global Change Biology 20: 3177-3190.

Clark DB \& Kellner JR. 2012. Tropical forest biomass estimation and the fallacy of misplaced concreteness. Journal of Vegetation Science 23: 1191-1196.

Cruz De León G \& Uranga-Valencia LP. 2013. Theoretical evaluation of Huber and Smalian methods applied to tree stem classical geometries. Bosque (Valdivia) 34: 311-317.

Deb JC, Halim MA \& Ahmed E. 2012. An allometric equation for estimating stem biomass of Acacia auriculiformis in the north-eastern region of Bangladesh. Southern Forests 74: 103-113.

Ebuy J, Lokombe JP, Ponette Q et al. 2011. Allometric equation for predicting aboveground biomass of three tree species. Journal of Tropical Forest Science 23: $125-132$.

FEarnside PM. 2012. Brazil's Amazon forest in mitigating global warming: unresolved controversies. Climate Policy 12: 70-81.

Hassan M. 1994. Forest soils of Bangladesh. Journal of Forest Science 23: 1-11.

Holdridge LR. 1967. Life Zone Ecology. Tropical Science Center. San José.

Islam M, Rahman M \& BräUning A. 2018. Long-term hydraulic adjustment of three tropical moist forest tree species to changing climate. Frontiers in Plant Science doi:10.3389/fpls.2018.01761

Kalinganire A \& Pinyopusarek K. 2000. Chukrasia: biology, cultivation and utilisation. Pp 35 in ACIAR Technical Reports No. 49. CSIRO, Canberra.

Ketterings QM, Coe R, Van Noordwijk M et al. 2001. Reducing uncertainty in the use of allometric biomass equations for predicting above-ground tree biomass in mixed secondary forests. Forest Ecology and Management 146: 199-209.

Le Quéré C, Moriarty R, Andrew RM et al. 2014. Global carbon budget 2014. Earth System Science Data Discussions 7: 47-85.

Mahmood H, Siddique MRH, Saha S et AL. 2015. Allometric models for biomass, nutrients and carbon stock in Excoecaria agallocha of the Sundarbans, Bangladesh. Wetlands Ecology and Management 23: 765-774.

Mahmood H, Siddique MRH, Abdullah SMR et al. 2016. Manual for Building Tree Volume and Biomass Allometric Manual for Building Tree Volume and Bio- Mass Allometric Equation. Bangladesh Forest Department, Food and Agricultural Organization of the United Nations, Dhaka.

Mahmood H, Siddique MRH, Costello L et al. 2019a. Allometric models for estimating biomass, carbon 
and nutrient stock in the Sal zone of Bangladesh. IForest-Biogeosciences and Forestry 12: 69-75.

Mahmood H, Siddique MRH, Islam SMZ et al. 2019b. Applicability of semi-destructive method to derive allometric model for estimating aboveground biomass and carbon stock in the Hill zone of Bangladesh. Journal of Forestry Research. doi:10.1007/ s11676-019-00881-5

Mahmood H, Siddique MRH, Abdullah SMR et al. 2019c. Which option best estimates the above-ground biomass of mangroves of Bangladesh: pantropical or site and species-specific models? Wetlands Ecology and Management 27: 553-569.

Mahmood H, Siddique MRH, Abdullah SMR et al. 2020. Semi-destructive method to derive allometric aboveground biomass model for village forest of bangladesh: comparison of regional and pantropical models. Journal of Tropical Forest Science 32: 246-256.

Maulana SI, Wibisono Y \& Utomo S. 2016. Development of local allometric equation to estimate total aboveground biomass in Papua tropical forest. Indonesian Journal of Forestry Research 3: 107-118.

MAYER DG \& ButLer DG. 1993. Statistical validation. Ecological Modelling 68: 21-32.

Nam VT, Van Kuijk M \& Anten NPR. 2016. Allometric equations for aboveground and belowground biomass estimations in an evergreen forest in Vietnam. PLOS ONE. doi: 10.1371/journal.pone.0156827

Nelson BW, Mesquita R, Pereira JlG et al. 1999. Allometric regressions for improved estimate of secondary forest biomass in the central Amazon. Forest Ecology and Management 117: 149-167.

NJANA MA. 2017. Indirect methods of tree biomass estimation and their uncertainties: Southern Forests. Journal of Forest Science 79: 41-49.

Overman JPM, Witte HJL \& Saldarriaga JG. 1994. Evaluation of regression models for above-ground biomass determination in Amazon rainforest. Journal of Tropical Ecology 10: 207-218.
PARRESOL BR. 1992. Baldcypress height-diameter equations and their prediction confidence intervals. Canadian Journal of Forest Research 22: 1429-1434.

Picard N, Saint-Andre L \& Henry M. 2012. Manual for Building Tree Volume and Biomass Allometric Equations: From Field Measurement to Prediction. Food and Agricultural Organization of the United Nations, Rome, and Centre de Coopération Internationale en Recherche Agronomique pour le Développement, Montpellier.

Piñeiro G, Perelman S, Guerschman JP et al. 2008. How to evaluate models: Observed vs. predicted or predicted vs. observed? Ecological Modelling 216: 316-322.

Robinson AP \& Hamann JD. 2010. Forest Analytics with $R$ : an introduction. Springer, New York.

SAATchi SS, Harris NL, Brown S ET AL. 2011. Benchmark map of forest carbon stocks in tropical regions across three continents. Proceedings of the National Academy of Sciences 108): 9899-9904.

Sattar MA, Bhattacharjee D \& Kabir MF. 1999. Physical and Mechanical Properties and Uses of Timbers of Bangladesh. Bangladesh Forest Research Institute, Chittagong.

Sileshi GW. 2014. A critical review of forest biomass estimation models, common mistakes and corrective measures. Forest Ecology and Management 329: 237-254.

SPRUgel DG. 1983. Correcting for Bias in Log-Transformed Allometric Equations. Ecology 64: 209-210.

Tulyasuman N, Henry M, Secrieru M et al. 2012. Issues and challenges for the national system for greenhouse gas inventory in the context of REDD ${ }^{+}$Greenhouse Gas Measurement and Management 2: 73-83.

Van Breugel M, Ransijn J, Craven D et al. 2011. Estimating carbon stock in secondary forests: Decisions and uncertainties associated with allometric biomass models. Forest Ecology and Management 262: 1648 1657.

VANCLAY JK. 1995. Growth models for tropical forests: A synthesis of models and methods. Forest Science 41: $7-42$. 